\title{
Pemberian Jamu (Jahe, Kunyit, dan Temulawak) terhadap Performa Produksi Telur Burung Puyuh (Corturnix corturnix japonica)
}

\section{Giving Herbs (Ginger, Turmeric, and Curcuma) on Performance of Quail Egg Production (Coturnix Coturnix japonica)}

\author{
W. Tini, N. S. Asminaya*, dan A. Napirah \\ Jurusan Peternakan, Fakultas Peternakan, Universitas Halu Oleo, Kendari - Indonesia \\ *Corresponding E-mail: nur.asminaya@uho.ac.id \\ (Diterima: 11 November 2019; Disetujui: 29 Maret 2020)
}

\begin{abstract}
ABSTRAK
Jahe, kunyit dan temulawak telah banyak digunakan sebagai bahan baku jamu ternak dan dapat meningkatkan produktivitas ternak. Penelitian ini bertujuan untuk mengetahui produksi telur burung puyuh (Corturnix corturnix japonica) yang diberi jamu (jahe, kunyit, dan temulawak). Materi yang digunakan dalam penelitian ini yaitu 80 ekor burung puyuh betina fase layer yang dipelihara selama 6 minggu. Rancangan yang digunakan dalam penelitian ini adalah rancangan acak lengkap (RAL) dengan 4 perlakuan yaitu P0 (perlakuan kontrol), P1 (0,25\% ekstrak jamu), P2 (0,5\% ekstrak jamu), P3 (1\% ekstrak jamu) dan masingmasing perlakuan diulang 4 kali. Variabel penelitian meliputi mempengaruhi konsumsi pakan, produksi telur, bobot telur, konversi pakan, dan skor warna kuning telur. Data hasil penelitian dianalisis dengan menggunakan analisis ragam dan perlakuan memberikan pengaruh yang nyata dilanjutkan dengan uji beda nyata terkecil (BNT). Hasil penelitian menunjukkan bahwa pemberian ekstrak jamu tidak mempengaruhi konsumsi pakan, produksi telur, bobot telur, konversi pakan, dan skor warna kuning telur. Nilainya secara berturut-turut berkisar antara 27,40-27,53 g/ekor/hari; 73,04-81,61\%; 10,67-11,26 g/ekor; 3,05-3,57 dan $5,75-7,50$. Penambahan ekstrak jamu hingga $1 \%$ pada air minum belum mampu meningkatkan produksi telur burung puyuh.
\end{abstract}

Kata Kunci: burung puyuh, jahe, kunyit, temulawak

\section{ABSTRACT}

Ginger, turmeric, and curcuma have been widely used as herbal raw materials and increase livestock productivity. This study aims to determine quail egg production (Corturnix corturnix japonica) given herbal (ginger, turmeric, and ginger). About 80 female layers of quail were used and maintained for six weeks. The research design used in this study was a completely randomized design with four treatments, i.e., P0 (control), P1 (0.25\% herbal extract), P2 (0.5\% herbal extract), P3 (1\% herbal extract) and each treatment was repeated four times. Research variables include feed intake, egg production, egg weight, feed conversion, and egg yolk color score. The data were analyzed using analysis of variance and continued with the least significant difference test (LSD). The results showed that the administration of herbal extract did not affect feed intake, egg production, egg weight, feed conversion, and egg yolk color score. The values range from 27.40-27.53 g/head/day, 73.04-81.61\%; 10.67-11.26 g/head; 3.05-3.57 and 5.75-7.50 respectively. It was concluded that the addition of herbal extracts up to $1 \%$ in drinking water has not been able to increase quail egg production.

Keywords: quail, ginger, turmeric, Curcuma 


\section{PENDAHULUAN}

Burung puyuh (Corturnix corturnix japonica) merupakan jenis unggas yang banyak diternakkan dengan tujuan untuk menghasilkan telur karena produksinya berkisar antara 200-300 butir/tahun (Amo et al., 2013). Produktivitas burung puyuh dipengaruhi oleh pakan (Dionysius, 2016), kondisi lingkungan Karnaen dan Arifin (2009), kebersihan lingkungan Esen et al. (2006). Pakan puyuh harus tersedia dalam jumlah yang cukup dan kualitas yang baik Anggitasari et al.(2016). Salah satu cara yang dapat dilakukan untuk meningkatkan konsumsi pakan dan produktivitas burung puyuh adalah dengan pemberian jamu. Akan tetapi level penggunaan yang tepat bagi produktivitas burung puyuh belum diketahui secara pasti sehingga perlu dilakuan penelitian.

Jamu yang dikonsumsi oleh manusia sebagai ramuan tanaman obat dapat digunakan untuk kesehatan hewan (Zainuddin, 2010). Jamu ternak merupakan bahan aditif pakan yang dapat meningkatkan pertambahan bobot badan dan menurunkan tingkat konversi pakan (FCR) serta meningkatkan kekebalan tubuh (Sudirman, 2012).

Bahan ramuan tanaman obat seperti jamu dibuat dari beberapa jenis tanaman obat antara lain: jahe, kunyit dan temulawak sesuai kepentingan dan fungsinya. Nursal et al. (2006) menyatakan bahwa senyawa senyawa flavonoid, fenol dan terpenoid yang terkandung pada jahe dapat merangsang kelenjar pencernaan, melancarkan peredaran darah dan pengeluaran empedu, antipiretik, antiinflamasi serta antibakteri. Pada temulawak, minyak atsiri dan kurkumin dapat melarutkan lemak dan menurunkan kadar kolestrol serta pencernaan dan penyerapan lemak. Menurut Wijayakusuma (2003) minyak atsiri dan kurkumin dapat meningkatkan pencernaan karbohidrat, lemak dan protein melalui pengeluaran getah pankreas disertai enzim amylase, lipase dan protease yang selanjutnya mempercepat pengosongan lambung.
Terkait dengan hal tersebut, maka perlu dilakukan penelitian tentang performa produksi telur burung puyuh (Conturnix conturnix japonica) dengan pemberian jamu (jahe, kunyit, dan temulawak).

\section{METODE}

Penelitian ini dilaksanakan di Laboratoriun Unit Ilmu Ternak Unggas Fakultas Peternakan, Universitas Halu Oleo, Kendari, menggunakan burung puyuh betina fase layer (Cortunix cortunix japonica) umur 15 minggu sebanyak 80 ekor. Pakan yang digunakan antara lain jagung, dedak, konsentrat RK 24 serta jamu yang diformulasikan dari jahe, temulawak, dan kunyit. Komposisi kandungan nutrisi pakan yang digunakan disajikan pada Tabel 1 dan 2.

Pembuatan jamu dilakukan setiap hari pada pukul 07.30 WITA. Jamu dibuat dengan cara memodifikasi proses pembuatan jamu menurut Yuliana (2016) yaitu: sebanyak $25 \mathrm{~g}$ jahe, $25 \mathrm{~g}$ kunyit, dan $25 \mathrm{~g}$ temulawak, dicuci sampai bersih, diiris tipis, diblender dengan $100 \mathrm{ml}$ air setelah itu disaring dan diambil ekstrak jamu.

Kandang yang digunakan adalah kandang battery sebanyak dua buah yang terdiri dari dua tingkat. Setiap tingkat terdiri dari 5 (lima) petak dan setiap petak berisi 5 ekor burung puyuh betina. Kandang tersebut terbuat dari kayu yang dilengkapi dengan ram kawat sebagai dinding sekaligus sebagai sekat pembatas antar petak. Ukuran tiap petak memiliki panjang $30 \mathrm{~cm}$, lebar $35 \mathrm{~cm}$ dan tinggi $35 \mathrm{~cm}$. Kandang yang digunakan terlebih dahulu disucihamakan dengan menggunakan desinfektan fermodes. Hal ini bertujuan untuk mencegah kontaminasi mikroorganisme parasit atau bakteri yang akan memberikan dampak buruk terhadap burung puyuh. Burung puyuh umur 15 minggu ditempatkan secara acak didalam kandang. Pakan diberikan sebanyak 2 kali sehari pada pukul 07.00 WITA dan sore 16.00 WITA. Pemberian air minum dilakukan 
Tabel 1. Komposisi kandungan nutrisi bahan pakan penelitian

\begin{tabular}{lcccc}
\hline Bahan Pakan & EM (Kkal/kg) & PK (\%) & LK (\%) & SK (\%) \\
\hline Konsentrat RK 24 & 3.300 & 35,00 & 8,00 & 3,00 \\
Jagung & 3.430 & 9,46 & 2,20 & 2,68 \\
Dedak & 1.630 & 9,29 & 8,50 & 16,54 \\
\hline
\end{tabular}

Tabel 2. Susunan pakan yang digunakan Selama Penelitian

\begin{tabular}{lc}
\hline Bahan Pakan & Perlakuan (\%) \\
\hline Kosentrat RK 24 (\%) & 40,00 \\
Jagung (\%) & 40,00 \\
Dedak (\%) & 20,00 \\
\hline Total (\%) & 100,00 \\
\hline Kandungan Nutrisi Pakan: & \\
EM (Kkal/kg) & $3.018,00$ \\
PK (\%) & 19,64 \\
LK (\%) & 5,78 \\
SK (\%) & 5,58 \\
\hline
\end{tabular}

Keterangan: EM= Energi Metabolisme, $\mathrm{PK}=$ Protein Kasar, $\mathrm{LK}=$ Lemak Kasar, $\mathrm{SK}=$ Serat Kasar.

pada pukul 08.00 WITA secara adlibitum dengan ditambahkan jamu sesuai perlakuan. Pembiasaan perlakuan dilakukan selama 2 minggu sebelum penelitian. Penimbangan sisa pakan (g) dan bobot telur (g) dilakukan setiap hari sebelum jam 07.00 WITA selama 6 minggu pemeliharaan.

Penelitian ini menggunakan Rancangan Acak Lengkap (RAL) yang terdiri dari 4 perlakuan dan 4 ulangan, dimana setiap ulangan terdiri dari 5 ekor burung puyuh dengan susunan perlakuan sebagai berikut:

$\mathrm{P} 0=$ Air minum tanpa ekstrak jamu

$\mathrm{P} 1=0,25 \%$ ekstrak jamu per liter air

$\mathrm{P} 2=0,5 \%$ ekstrak jamu per liter air

$\mathrm{P} 3=1 \%$ ekstrak jamu per liter air

Variabel yang diamati dalam penelitian ini adalah: konsumsi pakan (Rasyaf, 2006), produksi telur (Alwi, 2014), bobot telur (Setiawan, 2006), konversi pakan (Maknun et al., 2015), dan score warna kuning telur berdasarkan The Roche Yolk Color Fan (Akbarillah et al., 2008).

Data yang diperoleh dianalisis menggunakan analisis ragam untuk mengetahui pengaruh perlakuan terhadap variabel penelitian. Perlakuan berpengaruh nyata maka dilakukan uji lanjut dengan uji beda nyata terkecil (BNT) Hanafiah (2008).

\section{HASIL DAN PEMBAHASAN}

Pemberian ekstrak jamu pada air minum burung puyuh tidak memperlihatkan pengaruh yang nyata $(\mathrm{P}>0,05)$ terhadap konsumsi pakan, produksi telur, bobot telur dan konversi pakan, akan tetapi dapat mempengaruhi $(\mathrm{P}<0,05)$ skor warna kuning telur burung puyuh (Tabel 1). Warna kuning telur yang paling baik diperoleh pada penambahan $1 \%$ jamu pada air minum burung puyuh.

\section{Konsumsi pakan}

Pemberian ekstrak jamu tidak berpengaruh nyata $(\mathrm{P}>0,05)$ terhadap konsumsi pakan burung puyuh. Natamijaya (2005) menyatakan bahwa minyak atsiri dan kurkumin sebagai zat aktif dalam kunyit 
Tabel 3. Nilai Rataan Konsumsi Pakan, Produksi Telur, Bobot Telur, Konversi Pakan dan Skor Warna Kuning telur burung puyuh yang diberi ekstrak jamu

\begin{tabular}{lcccc}
\hline \multirow{2}{*}{ Variabel } & \multicolumn{4}{c}{ Perlakuan } \\
\cline { 2 - 5 } & P0 & P1 & P2 & P3 \\
\hline Konsumi Pakan (g/ & $27,40 \pm 0,27$ & $27,50 \pm 0,34$ & $27,41 \pm 0,42$ & $27,53 \pm 0,36$ \\
ekor/hari) & $81,61 \pm 4,68$ & $78,21 \pm 10,57$ & $80,89 \pm 11,29$ & $73,04 \pm 9,17$ \\
Produksi Telur (\%) & $11,03 \pm 0,23$ & $10,93 \pm 0,51$ & $11,26 \pm 0,65$ & $10,67 \pm 0,42$ \\
Bobot Telur (g/ekor) & $3,05 \pm 0,15$ & $3,26 \pm 0,43$ & $3,05 \pm 0,35$ & $3,57 \pm 0,50$ \\
Konversi Pakan & $5,75^{\mathrm{b}} \pm 0,50$ & $7,25^{\mathrm{b}} \pm 0,96$ & $7,25^{\mathrm{b}} \pm 0.50$ & $7,50^{\mathrm{a}} \pm 0,58$ \\
Skor Warna & & & & \\
Kuning Telur & &
\end{tabular}

Keterangan: $\mathrm{P} 0=$ tanpa ekstrak jamu, $\mathrm{P} 1=0,25 \%$ ekstrak jamu, $\mathrm{P} 2=0,5 \%$ ekstrak jamu, $\mathrm{P} 3=1 \%$ ekstrak jamu; ${ }^{a}$ Superskrip yang berbeda pada baris yang sama menunjukkan perbedaan yang nyata $(\mathrm{P}<0,05)$.

dapat mempercepat pengosongan isi lambung sehingga meningkatkan nafsu makan dan memperlancar proses pengeluaran empedu. Akan tetapi pada penelitian ini, pemberian level ekstrak jamu tidak memperlihatkan peningkatan konsumsi pakan yang signifikan. Hal ini kemungkinan disebabkan oleh kandungan jamu seperti kurkumin dan minyak atsiri belum dapat terserap dengan baik oleh burung puyuh. Penelitian serupa juga dilakukan oleh Yuliana (2016) terhadap konsumsi pakan ayam kampung yang diberi $3 \%$ jamu per liter air tidak menunjukan perbedaan yang nyata. Toana (2017) menyatakan bahwa pemberian air minum mengandung kunyit tidak berpengaruh nyata terhadap konsumsi pakan (866,7-893 g).

Rataan konsumsi pakan burung puyuh selama penelitian berkisar antara 27,40 $27,53 \mathrm{~g}$ /ekor/hari. Hal ini tidak jauh berbeda dengan penelitian Yildiz et al. (2004) yaitu 29,63 g/ekor/hari. Konsumsi pakan pada penelitian ini masih berada pada kisaran normal untuk burung puyuh. Achmaru et al. (2011) menyatakan bahwa konsumsi pakan normal burung puyuh yaitu $17,50-29,63 \mathrm{~g} /$ ekor/ hari.

Ferket and Gernet (2006) menyatakan bahwa konsumsi pakan dipengaruhi oleh formulasi dan ketersedian ransum, tersedianya air di dalam kandang, sanitasi lingkungan, kepadatan kandang serta kontrol terhadap penyakit.

\section{Produksi Telur}

Pemberian ekstrak jamu tidak memberikan pengaruh nyata $(\mathrm{P}>0,05)$ terhadap produksi telur. Rataan produksi telur pada penelitian ini berkisar antara 73,04 $81,61 \%$. Hal ini menunjukkan bahwa puyuh yang diberi jamu yang dicampurkan dalam air minum memiliki produktivitas yang relatif sama dengan perlakuan kontrol. Produksi telur pada penelitian ini cukup baik karena mencapai $80 \%$ dari jumlah ternak betina produktif perhari, sesuai dengan pendapat Panenkanan et al. (2013).

Produksi telur pada penelitian ini tidak menunjukan perbedaan yang signifikan kemungkinan disebabkan karena metode ekstraksi yang digunakan menggunakan pelarut air. Diduga media ekstraksi berupa air yang tidak melarutkan zat-zat bioaktif jamu secara optimal.

Luthfi et al. (2015) mengemukakan penambahan larutan ekstrak kunyit (Curcuma domestica) menggunakan bahan pelarut air dalam air minum burung puyuh tidak berpengaruh nyata terhadap produksi telur. Akbarillah et al. (2010) menjelaskan bahwa jumlah dan nutrisi pakan akan mempengaruhi produksi telur karena sebagian besar pakan yang dikonsumsi akan dikonversikan menjadi 
telur, jika kebutuhan hidup pokok telah terpenuhi pada unggas petelur. Kualitas dan konsumsi pakan pada penelitian ini telah memenuhi standar kebutuhan hidup pokok burung puyuh sehingga dapat digunakan untuk produksi telur puyuh.

\section{Bobot Telur}

Pemberian ekstrak jamu tidak berpengaruh nyata $(\mathrm{P}>0,05)$ terhadap bobot telur. Hal ini kemungkinan dikarenakan dosis jamu yang diberikan masih rendah sehingga tidak mempengaruhi bobot telur. Peningktan bobot telur sangat dipengaruhi oleh kandungan protein dalam pakan. Hal ini menunjukan bahwa pemberian ekstrak jamu hingga $1 \%$ dalam air minum tidak mempengaruhi peningkatan penyerapan protein sehingga pemberian ekstrak jamu dalam air minum belum dapat meningkatkan bobot telur.

Hasil rataan bobot telur burung puyuh selama penelitian yaitu berkisar antara 10,67 - 11,26 g/ekor. Hasil tersebut sesuai dengan penelitian Eishu et al. (2005) yang menyatakan bahwa bobot telur burung puyuh yang berumur $20-21$ dan $31-32$ minggu berkisar antara 10,1 dan 11,0 gram/ekor. Bobot telur pada penelitian ini masih berada pada kisaran normal. Song et al. (2000) rata - rata bobot telur puyuh normal adalah 10,34 g butir. Yuwanta (2007) menyatakan bahwa bobot telur dipengaruhi oleh jenis dan jumlah pakan yang dikonsumsi, genetik, lingkungan kandang serta ukuran tubuh induk.

\section{Konversi Pakan}

Pemberian ekstrak jamu pada air minum tidak berpengaruh nyata $(\mathrm{P}>0,05)$ terhadap konversi pakan. Rataan konversi pakan puyuh pada penelitian ini berkisar antara 3,05 - 3,57. Nilai konversi pakan pada penelitian ini lebih renda dari pada standar. Hazim et al. (2010) menyatakan bahwa konversi pakan idealnya yaitu $3,76-4,71$. Semakin kecil nilai konversi pakan menunjukkan bahwa pakan yang diberikan semakin efisien, demikian pula sebaliknya jika nilanya lebih besar maka pakan yang diberikan boror. Konversi pakan mencerminkan berhasil atau tidaknya penyususnan pakan yang dilakukan. Hal ini menunjukkan bahwa penambahan ekstrak jamu dalam air minum hingga taraf $1 \%$ belum dapat mengefisienkan konversi pakan.

Sejalan dengan hasil penelitian Yuliana (2016) bahwa penambahan jamu ternak dalam air minum ayam kampung tidak berpengaruh nyata terhadap konversi pakan. Nilai konsumsi pakan, produksi telur dan bobot telur pada semua perlakuan tidak berbeda, sehingga nilai konversi pakan pada semua perlakuan juga tidak berbeda. Palupi et al. (2016) menyatakan bahwa konversi ransum dipengaruhi oleh faktor genetik, sanitasi kandang, jenis dan kualitas pakan, kualitas air, timbulnya penyakit dan cara pengobatan serta manajemen pemeliharaan ternak.

\section{Skor Warna Kuning Telur}

Berdasarkan hasil sidik ragam diketahui bahwa pemberian ekstrak jamu pada air minum memberikan pengaruh nyata $(\mathrm{P}<0,05)$ terhadap skor warna kuning telur. Hal ini disebabkan oleh bahan baku jamu seperti kunyit dan temulawak mengandung zat aktif kurkuminoid sebagai pemberi warna (pigmen) kuning sehingga dapat mempengaruhi skor warna kuning telur. Hasil penelitian ini sejalan dengan Rachmat (2008) dan Amin et al. (2015) yang memperlihatkan peningkatan warna kuning telur setelah penambahan larutan ekstrak kunyit (Curcuma domestica) dalam air minum.

Skor warna kuning telur terbaik pada penelitian ini adalah 7,50 pada pemberian $1 \%$ ekstrak jamu dalam air minum. Hasil penelitian ini tidak jauh berbeda dengan Rachmat (2008) yang memperlihatkan skor warna 8 . Menurut Rachmat (2008), ekstrak jamu herbal yang mengandung zat aktif kurkuminoid sebagai pemberi warna (pigmen) kuning. Skor warna yolk yang tinggi pada telur dapat terbentuk jika $\beta$-caroten dan xantophil yang terdapat dalam pakan dikonsumsi dan dicerna dengan baik oleh unggas (Akbarillah et al., 2008),

Suharja (2010) menyatakan bahwa kandungan lemak mempengaruhi proses metabolisme karotenoid karena karotenoid 
larut dalam lemak dan sistim pencernaannya dibantu oleh tersedianya garam empedu yang dihasilkan oleh hati.

\section{KESIMPULAN DAN SARAN}

\section{Kesimpulan}

Penambahan ekstrak jamu hingga 1\% pada air minum belum dapat meningkatkan produksi telur burung puyuh.

\section{Saran}

Perlu dilakukan penelitian tentang penggunaan jamu ternak dengan metode ekstraksi berbeda sehingga dapat mengekstraksi bahan atau senyawa aktif pada jamu dengan lebih optimal.

\section{DAFTAR PUSTAKA}

Achmaru., Muherlien, dan Salaby. 2011. Pengaruh lantai kandang (rapat dan renggang) dan imbangan jantan betina terhadap konsumsi pakan, bobot telur, konversi pakan, dan tebal kerabang pada burung puyu. J. Ternak Tropikavol. 12(2): 1-14.

Akbarillah, T., Kususiyah, dan D. K. Hidayat. 2008. pengaruh suplemen tepung daun indigofera pada tepung geplek sebagai sumber energi pengganti jagung kuning dalam ransum puyuh (Coturnix coturnix japonica) terhadap produksi dan kuning telur. Jurnal Sains peternakan Indonesia. 3(1):51 - 55.

Akbarillah., T, Kususiyah, dan Hidayat. 2010. Pengaruh penggunaan daun indigofera segar sebagai suplemen pakan terhadap produksi dan warna yolk itik. Jurnal Sain Peternakan Indonesia. 5(1): 27 33.

Alwi, W. 2014. Pengaruh Imbangan Energi Protein Terhadap Performa Ayam Arab. Fakultas Peternakan, Universitas Hasanuddin. Makassar.

Amin, N. S., Anggraeni, dan E. Dihansih. 2015. Pengaruh penambahan larutan ekstrak kunyit (Curcuma domestica) dalam air minum terhadap kualitas telur burung puyuh. Jurnal Peternakan Nusantara. 1(2): 115 - 125.

Amo, M., J. L. P. Saerang., M. Najoan, dan J. Keintjem. 2013. Pengaruh penambahan tepung kunyit (Curcuma domestica val) dalam ransum terhadap kualitas telur puyuh (Corturnix-corturnix japonica). Jurnal Zootek 33(1): 48-57.

Anggitasari, S., Sjofjan, O. dan Djunaidi, I. H. 2016. Pengaruh beberapa jenis pakan komersial terhadap kinerja produksi kuantitatif dan kualitatif ayam pedaging. Buletin Peternakan 40(3): 187-196

Dionysius, A. W. M. 2016. Pengaruh Jenis Burung Puyuh (Coturnix-coturnix japonica) dengan Pemberian Pakan Komersial yang Berbeda Terhadap Penampilan Produksi Periode Bertelur. J. Ternak Tropika 17(2): 43-49.

Eishu, R. I., Katsunori, S., Takuro, O., Kunieda, T. and Hideji, U. 2005. Effects of dietary protein levels on production and caracteristics of japanese quail egg. J Poult Sci. 42(2): 130-139.

Esen. F., G. Özdemir, and O. Özbey. 2006. The effect of cage stocking density on growth, slaughtering and carcas characteristics of rock partridges (A. Graeca). Int. J. Poultry Sci. 5 (1): 04-08.

Ferket, P. and A. G. Gernet. 2006. Factors That Effect Feed Intake of Meat Birds: A Review. J. Poultry Sci. 5(10): 905911.

Hanafiah, K. A. 2008. Rancangan Percobaan Aplikatif Teori \& Aplikasi. Jakarta: PT Raja Grafindo Persada.

Hazim, J. A., Razuki, W. M., Al-Hayani, W. K. and Al-Hassani, A. S. 2010. Effect of dietary linseed on egg quality of laying quail. Int J Poult Sci 9(6): 584-580.

Karnaen dan J. Arifin. 2009. Korelasi Nilai Pemuliaan Produksi Susu Sapi Perah 
berdasarkan Test Day Laktasi 1, Laktasi 2, Laktasi 3, dengan Gabungannya. J. Anim. Production 11: 135-142.

Luthfi, M. I., H. Nur, dan Anggraeni. 2015. Pengaruh pemberian larutan ekstrak kunyit (Curcuma domestika) dalam air minum terhadap produksi telur burung puyuh (Coturnix-coturnix japonica). Jurnal Peternakan Nusantara. 1(2) : 8188.

Maknun, L., Sri, K dan Isna, M. 2015. Performans produksi burung puyuh (Coturnix coturnix japonica) dengan perlakuan tepung limbah penetasan telur puyuh. Jurnal Ilmu - ilmu Peternakan. 25(3): 53-58.

Natamijaya, A. G. 2005. Karakteristik penampilan pola warna bilu, kulit, sisik, dan paruh ayam pelung di garut dan ayam sentul di Ciamis. Buletin Plasma Nutfah. 10 (1): 1 - 10.

Nursal, S., Wulandari, dan W. S. Juwita. 2006. Bioaktivitas ekstra jahe (Zingiber officinale roxb) alam menghambat pertumbuhan koloni bakteri esherichia coli dan bacillus sublitis. Jurnal Biogenesis. 2(2): 64 - 66.

Palupi., R. E. Sahara, dan Purwuto. 2016. Level Tepung kulit ubi kayu fermentasi dalam ransum terhadap performa produksi puyuh umur $1-8$ minggu. Jurnal Peternakan Sriwijaya. 5(1):1017.

Panekanan., O. Jusuf., C. Loing., B. Rorimpandey, dan P. O. V. Waleng. 2013. Anlisis keuntungan usaha beternak puyuh di Kecamatan Sonder Kabupaten Minahasa. Jurnal Zootek. 32(5): $1-10$.

Rachmat, K. 2008. Pengaruh Penambahan Tepung Kunyit (Curcuma domestica Val.) dalam Ransum Yang Diberi Minyak Jelantah terhadap Performan Ayam Broiler. Jurnal Ilmu Ternak. 8(1): $25-30$.
Rasyaf, M. 2006. Manajemen peternakan ayam kampung. Kanisius. Yogyakarta.

Setiawan, D. 2006. Performan produksi burung puyuh (Corturnix corturnix japonica) pada perbandingan jantan dan betina yang berbeda. [Skripsi]. Program Studi Teknologi Produksi Ternak, Fakultas Peternakan. Institut Pertanian Bogor.

Song, K. T., Choi, S. H. and Oh, H. R. 2000. A Comparison of Egg Quality of Pheasant, Chukar, Quail and Guinea Fowl. Asian-Australasian Journal of Animal Sciences. 13(7): 986-990.

Sudirman, H. 2012. Pemanfaatan Tanaman Obat Sebagai Jamu Untuk Ayam Buras. Jurnal Agrisistem. 8(1): 49 - 56.

Suharja. 2010. Mengendalikan Pigmentasi Kuning Lewat Pakan. Feed TeknoIndustri Pakan Ternak Indonesia.

Toana, N. M. 2017. Penggunaan kunyit dalam air minum terhadap penampilan produksi puyuh. Jurnal Agrisains 18 (2): $64-70$.

Wijayakusuma, H. 2003. Penyembuhan dengan temulawak. Millennia. Popular. Jakarta.

Yildiz, A. O., Parlat, S. S. and Yazgan, O. 2004. The effect of organic chromium supplementation on production traits and some parameters of laying quail. Revue Med Vet. 155: 642 - 646.

Yuliana. 2016. Penampilan produksi ayam kampung yang diberi jamu ternak melalui air minum. JITRO. 4(2).

Yuwanta, T. 2007. Telur dan Produksi Telur. Universitas Gadjah Mada Press. Yogyakarta.

Zainuddin, D. 2010. Tanaman Obat-Obatan. Balai Penelitian Tanaman Obat. Bogor. 